\title{
CYTOTOXICITY ACTIVITY OF PICRIA FEL-TERRAE LOUR. HERBS AGAINST 4T1 AND MCF-7 BREAST CANCER CELLS
}

\author{
URIP HARAHAP ${ }^{*}$, POPPY ANJELISA ZAITUN HASIBUAN ${ }^{1}$, PANAL SITORUS ${ }^{2}$, DENNY SATRIA ${ }^{2}$ \\ ${ }^{1}$ Department of Pharmacology, Faculty of Pharmacy, University of Sumatera Utara, Indonesia. ${ }^{2}$ Department of Pharmaceutical Biology, \\ Faculty of Pharmacy, University of Sumatera Utara, Indonesia. Email: uripharahap@usu.ac.id
}

Received: 07 March 2018, Revised and Accepted: 25 March 2018

\section{ABSTRACT}

Objective: This study was carried out to investigate the cytotoxic activity toward 4T1 and MCF-7 cell lines of Picria fel-terrae Lour. herb fractions.

Methods: P. fel-terrae Lour. herb powder was extracted by maceration method with n-hexane, ethyl acetate, and ethanol solvent. In vitro study was using MTT method toward 4T1 and MCF-7 cell lines.

Results: The inhibitory concentration $50 \%$ was $234.10 \pm 7.85,50.49 \pm 1.07$, and $212.53 \pm 7.55 \mu \mathrm{g} / \mathrm{mL}$ for $4 \mathrm{~T} 1$ and $84.62 \pm 1.44,56.79 \pm 0.22$, and $235.51 \pm 4.77 \mu \mathrm{g} / \mathrm{mL}$ for MCF-7 cell lines, respectively.

Conclusion: The results reveal that $P$. fel-terrae Lour. herb fractions provide effective as anticancer. Our further study is to assess the mechanism of ethyl acetate fraction in inhibit angiogenesis and metastatic in breast cancer.

Keywords: Cytotoxicity, Picria fel-terrae Lour., Herbs, Fractions, Cell lines.

(c) 2018 The Authors. Published by Innovare Academic Sciences Pvt Ltd. This is an open access article under the CC BY license (http://creativecommons. org/licenses/by/4. 0/) DOI: http://dx.doi.org/10.22159/ajpcr.2018.v11s1.26608

\section{INTRODUCTION}

The use of medicinal plant extracts for the treatment of human disease is an ancient practice and thus has greatly increased in recent years. Cancer is one of the most frequent and distressing diseases which increased during the last 50 years [1]. Research into plants with anticancer effects is still encouraged with a view to discover any new drugs with less toxic but more potent effects [2]. Indonesia has the potential diversity of plant species as medicinal plants. The World Health Organization reported that breast cancer is one of the leading causes of death and the most common cancer type among women worldwide in 2012 [3]. Moreover, breast cancer ranks as the $5^{\text {th }}$ cause of death from cancer overall (522,000 deaths), is the most frequent cause of cancer death in women in less developed countries $(324,000$ deaths, $14.3 \%$ of total), and the $2^{\text {nd }}$ cause of cancer death in developed countries (198,000 deaths, 15.4\%) after lung cancer. A previous study reported that breast cancer is predicted to be a leading new cancer cases and the $2^{\text {nd }}$ most common death cause of women suffering from cancer in the US [1]. Therefore, research and development in cancer detection and treatment is importantly required to solve those problems.

Breast cancer occurs when breast cells start to grow uncontrollably. These cells can invade nearby tissues and spread throughout the body. Each type of tissue in the breast can form a cancer, but the cancer usually arises in the milk ducts or glands. Factors that influence the risk of breast cancer are the length of exposure to hormones (e.g., menstruation at an early age or late menopause), reproductive factors (e.g., no children and first pregnancy at an advanced age), dietary factors and lack of physical activity (e.g., obesity and dietary fat), radiation during breast development, hormone replacement therapy on chronic use, as well as congenital genetic factors associated with breast cancer like the presence of gene mutations [4].

Poguntano (Picria fel-terrae Lour.) has been used as drug of colic, malaria, diuretic, fever, and skin disease [5]. Modern pharmacological investigations indicated that the extract of $P$. fel-terrae Lour. exerts diuretic, antipiretic, hepatoprotective, cardioprotective, antidiabetic, antioxidant (high content of flavonoid and phenol), anti-inflammatory, anthelmintic, and analgesic activities [6-15]. Moreover, P. fel-terrae inhibits hepatitis B (HB) e-antigen excreted by HepG2 2215 cell lines, suggesting to have anti-HB virus activity [16]. It can be developed as cochemotherapeutic regimen for breast cancer by inducing apoptosis and cell cycle arrest and suppressing cyclin D1 and Bcl-2 expression based on the recent studies $[17,18]$. The aim of this study was to determine cytotoxic activity of n-hexane, ethyl acetate, and ethanol fractions of $P$. fel-terrae Lour. herbs toward 4T1 and MCF-7 cell line.

\section{METHODS}

Plant and chemicals material

Fresh herbs of $P$. fel-terrae Lour. were collected from Tiga Lingga village, Dairi regency, Sumatera Utara province, Indonesia. P. fel-terrae Lour. was identified in Research Centre for Biology, Indonesian Institute of Science, Bogor, and the voucher specimen was deposited in herbarium. Chemicals used were distilled water, dimethyl sulfoxide (Sigma), and [3-(4,5-dimethylthiazole-2-yl)-2,5-diphenyl tetrazolium bromide] (MTT) (Sigma).

\section{Preparation of ethyl acetate fraction (EAF)}

The air-dried and powdered herbs of $P$. fel-terrae Lour. $(1 \mathrm{~kg})$ were repeatedly fractionated by cold maceration with $n$-hexane $(3 \times 3$ day, $7.5 \mathrm{~L})$. The powder was dried in the air and fractionated with ethyl acetate $(3 \times 3$ day, $7.5 \mathrm{~L})$. The powder was dried in the air and fractionated with ethanol $96 \%(3 \times 3$ day, $7.5 \mathrm{~L})$ at room temperature with occasional stirring. The filtrate was collected and then evaporated under reduced pressure to give a viscous fraction and then freeze dried to dry $[17,19,20]$.

\section{Cytotoxicity assay}

The cells were treated with $n$-hexane, ethyl acetate, and ethanol fractions. In this test, 4T1 and MCF-7 cell line were grown in Dulbecco's modified eagle medium, medium containing 10\% fetal bovine serum (Gibco), $1 \%$ penicillin-streptomycin (Gibco), and fungizone $0.5 \%$ (Gibco) in a flask in a humidified atmosphere $\left(5 \% \mathrm{CO}_{2}\right)$ at $37^{\circ} \mathrm{C}$. The inoculums seeded at $1 \times 10^{4}$ cells $/ \mathrm{mL}$ at an optimal volume of $0.1 \mathrm{~mL}$ per well. After $24 \mathrm{~h}$ incubation, the medium was discharged and treated by n-hexane, ethyl acetate, and ethanol fractions. After incubation $24 \mathrm{~h}$, the cells were incubated with $0.5 \mathrm{mg} / \mathrm{mL}$ MTT for $4 \mathrm{~h}$ in $37^{\circ} \mathrm{C}$. Viable cells reacted with MTT to produce purple formazan crystals. After $4 \mathrm{~h}$, SDS $10 \%$ as stopper 
Table 1: $\mathrm{IC}_{50}$ value of $\mathbf{n}$-hexane, ethyl acetate, and ethanol fraction of $P$. fel-terrae Lour. herbs toward 4T1 and MCF-7 cells

\begin{tabular}{lll}
\hline Fraction & IC $_{\mathbf{5 0}}(\boldsymbol{\mu g} / \mathbf{m L})$ & \\
\cline { 2 - 3 } & $\mathbf{4 T 1}$ & MCF-7 \\
\hline n-hexane & $234.10 \pm 7.85$ & $84.62 \pm 1.44$ \\
Ethyl acetate & $50.49 \pm 1.07$ & $56.79 \pm 0.22$ \\
Ethanol & $212.53 \pm 7.55$ & $235.51 \pm 4.77$ \\
\hline
\end{tabular}

IC50: Inhibitory concentration $50 \%$

(Sigma) in $0.01 \mathrm{~N} \mathrm{HCl}$ (Merck) was added to dissolve the formazan crystals. The cells were incubated for $24 \mathrm{~h}$ in room temperature and protected from light. After incubation, the cells were shaken, and absorbance was measured using enzyme-linked immunosorbent assay reader at $\lambda 595 \mathrm{~nm}$. The data which were absorbed from each well was converted to percentage of viable cells $[20,21]$.

The equation to determine viability of cells:

Viability $=\frac{\text { Abs of treatment }- \text { Abs of medium }}{\text { Abs of control cells-Abs of medium }} \times 100 \%$

\section{RESULTS AND DISCUSSION}

\section{Plant authentication}

Plant authentication was identified in Research Centre for Biology, Indonesian Institute of Science, Bogor, and the voucher specimen was deposited in herbarium with number of 332/IPH.1.01/If.07/II/2016 and was showed species of $P$. fel-terrae (Lour.).

\section{Inhibitory concentration $\mathbf{5 0 \%}\left(\right.$ IC $_{50}$ )}

MTT method was used to determine cell viability after incubation for $24 \mathrm{~h}$. Cytotoxic activity of n-hexane, ethyl acetate, and ethanol fraction of herbs of P. fel-terrae Lour. was shown in Table 1.

In every treatment, n-hexane, ethyl acetate, and ethanol fraction were shown to inhibit cells growth. The highest $\mathrm{IC}_{50}$ value was obtained from EAF of $P$. fel-terrae Lour. herbs of $50.49 \pm 1.07 \mu \mathrm{g} / \mathrm{mL}$ toward $4 \mathrm{~T} 1$ cell lines and $56.79 \pm 0.22 \mu \mathrm{g} / \mathrm{mL}$ toward MCF-7 cell lines. The estimated cytotoxicity of natural product is related to content of active compound in these plants including P. fel-terrae Lour. flavonoids, saponins, and tannins estimated as active compounds [13].

\section{ACKNOWLEDGMENTS}

We gratefully thank to Research Center University of Sumatera Utara through Hibah Talenta "Hibah Penelitian Unggulan Universitas" Research Grant 2017 “No: 5338/UN5.1.R/PPM/2017” for financial support in the study.

\section{REFERENCES}

1. Siegel RL, Miller KD, Jemal A. Cancer statistics. CA Cancer J Clin 2015;65:5-29.

2. Piyapat T, Sato A, Nishiwaki H, Tamura H. A new diterpene from Litsea cubeba fruits: Structure elucidation and capability to induce apoptosis in hela cells. Molecules 2014;19:6838-50.

3. WHO. World Cancer Report 2014; 2015.

4. Barnett GC. Risk factors for the incidence of breast cancer: Do they affect survival from the disease. Oncology 2008;26:3310-6.

5. Perry LM. Medicinal Plants of East and Southeast Asia. London. The MIT Press; 1980.

6. Dalimunthe A, Achmad S, Satria D. Phenolic, flavonoid content and antioxidant activities of ethylacetate extract of Litsea cubeba (Lour.) Pers. Barks. Pharm Chem 2016;8:466-8.

7. Huang Y, Cimanga K, Lasure A, Van Poel B, Pieters L, Berghevanden D. A Modulation of the complement system by flavonoid. World Sci 1994;7:16-8.

8. Thuan ND, Ha do T, Thuong PT, Na MK, Lee JP, Lee JH, et al. A phenylpropanoid glycoside with antioxidant activity from picria telferae. Arch Pharm Res 2007;30:1062-6.

9. Zhong SQ, Zhang BN, dan Huang FX. An antitumor herb cucao. Chin Tradit Herb Drugs Lett 1979; pp.45-6.

10. Zou JM, Wang LS, Niu XM, Sun HD, dan Guo YJ. Phenylethanoid glycosides from Picria fel-terrae Lour. J Integr Plant Biol 2005;47:632- 6 .

11. Harfina F, Bahri S, dan Saragih A. Effect of puguntano leaf powder (Curanga fel-terrae Merr.) in diabetes mellitus patients. J Pharm Pharmacol 2012;1:112-8.

12. Sitorus P, Urip H, Nasution MP, Barus T. Isolation of $\beta$-sitosterol from n-hexane extract of Picria fel-terrae Lour. Leave and study of its antidiabetic effect in alloxan induced diabetic mice. Int J Pharm Tech Res 2014;6:137-41.

13. Sihotang YM, Silalahi J, Hadisahputra S, Hasibuan PA, Satria D. Cardioprotective effect of ethylacetate extract of poguntano (Picria felterrae lour.) against doxorubicin-induced cardiotoxicity in rats. Int $\mathrm{J}$ Pharm Clin Res 2016;8:466-70.

14. Patilaya P, Dadang HI. Preliminary study on the anthelmintic activity of the leaf ethanolic extract of Indonesian Curanga fel-terrae. (Lour.) Merr Tech Res 2015;8:347-51.

15. Satria D, Silalahi J, Haro G, Ilyas S, Hasibuan PA. Antioxidant and antiproliferative activities of an ethylacetate fraction of Picria felterrae Lour herbs. Asian Pac J Cancer Prev 2017;18:300-403.

16. Zeng J, Pan X, Yang K, Wei Z, Chen C. Experimental study on the inhibitoryefect on HBeAg and HBsAg excreted by 2215 cells of different extracts of Picria fel-terrae Lour. Chin Med Herald 2010; 7:279.

17. Satria D, Furqan M, Hadisahputra S, Rosidah. Combinational effects of ethylacetate extract of Picria fel-terrae lour and doxorubicin on $477 \mathrm{~d}$ breast cancer cells. Int J Pharm Pharm Sci 2015;7:73-6.

18. Lestari P, Sumadio H, Syafruddin IJ. Combinational effects of n-hexane extract of poguntano leaves. (Picria fel-terrae Lour.) with doxorubicin on MCF-7 breast cancer cells. Chem Pharm Res 2015;7:353-5.

19. Anggraini R, Hadisahputra S, Silalahi J. Combinational effects of ethylacetate extract of Zanthoxylum acanthopodium dc. with doxorubicin on $\mathrm{t} 47 \mathrm{~d}$ breast cancer cells. Int $\mathrm{J}$ Pharm Tech Res 2014;6:2032-5.

20. Hasibuan PA, Jessy C, Satria D. Combination effect of ethylacetate extracts of Plectranthus ambonicius (lour.) spreng. with doxorubicin againts t47d breast cancer cells. Int J Pharm Pharm Sci 2015;7: 155-9.

21. Satria D, Nasution NP, Ilyas S. Cytotoxcicity effect of sea horse (Hippocampus trimaculatus leach.) extract and fractions on mcf-7 cell line. Int J Pharm Tech Res 2014;6:212. 